\title{
Sustainable or Sustainability?
}

\section{¿Sostenibilidad o Sustentabilidad?}

\author{
HIGUERA-ZIMBRÓN, Alejandro †* \& RIVERA-GUTIÉRREZ, Erika \\ Universidad Autónoma del Estado de México, Centro de Investigación en Arquitectura y Diseño.
}

ID $1^{\text {st }}$ Author: Alejandro, Higuera-Zimbrón / ORC ID: 0000-0002-7851-7531, Researcher ID Thomson: AAJ-7550-2020, SNI CONACYT ID: 226412

ID $1^{\text {st }}$ Coauthor: Erika, Rivera-Gutiérrez / ORC ID: 0000-0001-6966-2721, Researcher ID Thomson: AAJ-7948-2020, SNI CONACYT ID: 247442

DOI: $10.35429 / J S R .2020 .17 .6 .7 .21$

Received January 10, 2020; Accepted April 01, 2020

\begin{abstract}
The goal of this study discusses the frequency of use the term sustainable or sustainability translated in Spanish as sustentable or sostenible. Also, it is necessary to say that the problem is just regarding to the writing of this expression, but not the semantic meaning. It is important to clarify that, during this time has been a huge controversy, especially when this concept is writing in the spanish langue. In fact, there is a duality when authors write down in spanish sostenible or sustentable, because dictionaries argue that the word sustentable does not exist. So, in order to accomplish this goal, the first part is explained the origins of this word, then has been made a literature review based on the cooper taxonomy (1998). Also, the systematic review (Cochran Manual) analyzed the documents from many digital sources particularly those from government, institutions and plans or projects to comprehend the most practical use of these words. Finally, the results shown that there is no perfect use; the term is applied according to the context, but the semantic meaning represent the description of the study object.
\end{abstract}

Sustainable or Sustainability

\begin{abstract}
Resumen
Actualmente la palabra sostenibilidad o sustentabilidad es utilizada de forma permanente en múltiples sistemas comunicación. Empero, ¿cuál debería ser el término correcto para su aplicación? En consecuencia, este estudio se enfoca en esta interrogante; de ahí que se describieron los orígenes del término, se realizó una revisión de la literatura identificando estudios recientes, además se analizó el estado actual de las investigaciones entorno a estos constructos; complementado por algunos documentos oficiales de gobierno, instituciones o planes o programas, que hacen referencia a esta temática. Finalmente, posterior a un análisis de contenido de la información referida, se llegó a la conclusión de que impera más su semántica que su escritura. Los términos son usados indistintamente en algunos países; sin embargo, en la mayoría de las naciones se emplea la palabra sostenibilidad según sea el contexto.
\end{abstract}

Citation: HIGUERA-ZIMBRÓN, Alejandro \& RIVERA-GUTIÉRREZ, Erika. Sustainable or Sustainability?. Journal of Social Researches. 2020. 6-17: 7-21.

\footnotetext{
* Correspondence to Author (Email: ahigueraz@uaemex.mx)

$\dagger$ Researcher contributing as first author.
} 


\section{Introduction}

Man has lost his ability to anticipate and anticipate. It will end by destroying the earth Albert Schweitzer

The issue of sustainability or sustainability are part of the discussions in different social areas. Its analysis from multiple perspectives has been caused by the circumstances of everyday use. However, the semantic denomination has been a controversy in Spanish-speaking countries, especially from linguistic aspects to literary aspects. Element that could not be stopped analyzing and perhaps establishing a better argument for its use. For this reason, a variety of authors such as Álvarez et al (2020), RoldánGuzman (2020), Cedeño et al (2020), Lacherre (2018), Higuera et al (2016), Méndez (2012), Celi (2007), Fraume (2008), among others, share some perspectives and do the exercise of investigating the meaning based on some research; both historical and current.

Therefore, this document aims to establish a referential framework, based on various approaches, on which is the most frequent semantic use of the term sustainable or sustainable. Therefore, first, the background will be described, based on empirical evidence as a starting point to understand the origin of the term. Next, an analysis of the state of the art is made, using some leading authors in the field, without losing sight of the validity of the matter. Subsequently, from a case study, the most common uses from various spheres are shown; institutional, academic and social. The goal is to establish better arguments for its pertinent use in the different areas.

To achieve the purpose of this document, a systematic review of information was made. A documentary sample with the following structure was chosen; documents that come from scientific articles, plans, programs and projects, with a validity of no more than ten years to date, that came from reliable sources. The instrument that helped to collect the information arises from the Cochrane systematic reviews that classify and typify features that the documents must incorporate in each axis. The analysis of the information is done under a content technique. And the results are exposed during the development of the document. Finally some of the ideas were contrasted.

\section{Background}

As a result of deforestation that was exacerbating throughout Europe, Hans Carl von Carlowitz published in 1713 Silvicultura Económica (Sylvicultura Oeconnomica). Otero (2010), verifies that in the document the concept of sustainability (Nachhaltigkeit) was raised in the German language. The publication broadly enacted the cultivation, use and conservation of wood in a stable and sustainable manner. According to Schmithüsen (2013), the writing is evidence of the German term that designates sustainability, especially when referring to forest sustainability. It should be noted that the author's paraphrase, of German origin, is a member of the World Forestry Center (WFC), which does not refer to sustainability, but literally to the term Nachhaltigkeit, literally translated as sustainability in the Spanish language.

Bosselmann (2008) in Otero (2010), add that this term sustainability was isolated from forest schools in Germany, but curiously defined with all its meaning in countries such as AustriaHungary, Switzerland, France, Russia, Scandinavia, the United Kingdom and the United States. United of North America. However, the author confirms that there was a need to search for a word that was ideal for use in different languages. In 1837, Fracoise Parade, director of the Forest School of Nancy in France, translated it into French by production sustenau. Some time later it was adapted by the English to sustainable yield, which means sustainable production (Ulrich, 2010: 2). It is perhaps in this adaptation that the duality in the writing of the term arises, it was probably easier to write sustainable, because of the way the French and English translated it, than to write sustainable.

As appreciated by the interpretation of a variety of authors, the concept focuses its writing on ecology and society. For example; Sieferle (2003), considers that the ecological problems of society were oriented in the overexploitation of forests and their derivatives, based on the nature of agrarian civilizations and the industrial revolution. To quote Marquardt (2006) when the land was used to the limits of its ecological carrying capacity, there was systematic pressure to create lasting sustainability and standardize a system of standards for the use of the environment (p.172). 
In the previous section, the authors refer to two interrelated components, ecology and lasting sustainability, a correlation of terms relative to the long-term preservation, maintenance or maintenance of biodiversity is perceived. Variables that Escobar (2015) confirms when he clarifies that in praxis he refers to sustainable livelihoods, livelihoods of individuals or groups that allows them to improve their socioeconomic situation on a lasting basis, resisting possible crises and without damaging opportunities for future generations.

In this sense, regarding future generations, the United Nations (UN) report Our Common Future (1984) was considered by many to be the first document to mention generational justice; However, when reviewing what GeorgLudwig Hartig (1795) exposes in his book Anweisung zur Taxation der Forste oder zur Bestimmung des Holzertrags der Wälder, taken up by Schmithüsen (2013), it can be seen that for some centuries it had been raised, the perspective of sustainability from different dimensions; one of them intergenerational; because in light of the text he quoted:

It is not possible to develop ideas about sustainable forest exploitation... Consequently, wise forest management must proceed by imposing taxes... but aiming to use them in such a way that "Future generations can get at least the same advantages as the present ones" (p.6).

\section{Theoretical approach}

\section{Sustainable or sustainable construct}

In this literature review, it is stated that the topic, at least in Spanish-speaking countries, is interesting to generate some discussions in various academic settings. The authors decompose the term as necessary in order to provide arguments that validate its use par excellence. For this, an important range of scientific leaders make connections through linguistic or philological, conceptual and even theoretical perspectives, some others of uses and customs. For example, Márquez (2010) linguistically decomposes the terms sustainable and sustainable. Affirms that they are verbal or postverbal adjectives, because they derive from the same verbs, that is, the verbs to sustain and sustain, are mutual.
In addition, they belong to the type of adjectives that are formed by the, added to the root of the verb of the suffix able or ible, as denoted by the idea of passive possibility. However, the discussion is not about the suffix, but about the prefix sos or sus, which comes from Greek prefixes. From this the word sustain is derived, a verb that according to the Dictionary of the Spanish Language (DRAE), means that which is capable of sustaining. However, DRAE defines sustainability as what is capable of sustaining, especially "something" that can be defended with ideas or reasons (DRAE, 2014).

In any case, if those observations of the DRAE are applied to the sentence, it can be said that the word sustainable is what is capable of sustaining itself, and sustainable is what can be sustained. Now, it could be considered that both verbs from the semantic sense are synonyms. It should be noted that, in this deduction, the scientific scope of the term is not taken into account. But, a contradiction of the first approach is that on many occasions something that is sustained is not always something that is sustained, or conversely something that is sustained is not always sustained.

Bifani (1993), argues that the expressions sustainable or sustainable come from English words that have been integrated into the Spanish language (Anglicism), these words come from the construct sustainable development. It is imperative that every day countless English words are incorporated into the Spanish language, however, this does not mean that they mean the same thing. Although Tudela (1992) already warned about the possibility that this matter would become semantic difficulty. This author suggested an operational definition of the concept, whose characteristics could be defined as systematic networks of relationships were established (Tudela, 1992). Under this order of ideas, interpretations of Pepper (1998), Stathiendrakumar (1996), cited by Martins et al (2006), consider that the terms sustainability or sustainable development have been constantly used in the literature, however, the debate has been focused on the political application, from its uses and meanings, but not necessarily on the subject of the term. Although it must be specified, from the operational point of view, it seems that the term is constituted by a dichotomy focused on development or progress. 
In this sense, Fraume (2008) affirms that the sustainable tends to maintain conservation characteristics over economic means. In other words, there is a strong inclination of the balance on the macro and microeconomic aspects of production systems. However, for the term of sustainability it emphasizes maintaining the social and ecological elements with the aim of maintaining a long-term quality of life. The author considers that the purpose of a society will be to maintain in a balanced way the management of natural resources as long as it is constantly improved. By contrast, Torres (1992) cited by Gudynas (1992), recalls that, sustainable and sustainable are interpretations made during the Rio de Janeiro Brazil conference in 1992. The author states that each of the words was used and is used, depending on the focus and context, especially due to some ideological environmental trends in Latin America.

For example: Those individuals with anthropocentric perception, where they consider the human being as a central element of analysis, are only inclined to use the term sustainable, and those who consider everything inherent in life, from a biocentric perspective, use the term sustainable. (Gudynas, 1992: 104). The positions already note its semantic complexity, although the end, in any case, differs from the aforementioned development or progress position, rather, there is one more tendency to connote the social and environmental aspects of the matter.

These arguments are confirmed by Celi (2007), who not only clarifies that in the report of the conference in Rio de Janeiro in 1992 the term sustainable development was delimited, but also maintains that it was there where the confusion about the correct use of the word sustainable or sustainable (Celi, 2007).

Perhaps more recently, what Méndez (2012) explains is confusing: Sustainability and sustainability are, in principle, equal in their operation. The author makes a clarification: The application of the term will depend on the space and time in which it is used, that is, the place matters and the moment matters. Undoubtedly, it can be considered that said argument is not intended to conflict the user semantically, but quite the contrary, it can be interpreted that the use of both is allowed regardless of the context in which it is used.
The author agrees that there are no differences in applicability, in the strict sense of development or progress. His hypothesis affects that everything will depend on where the word is used. However, it clarifies that the only thing that is intended is what the United Nations (UN) points out, meeting the needs of the present generation without compromising the needs of future generations (Méndez, 2012). However, from a rational perspective, this position is irrelevant, the expression is indifferent for the purposes in which it was established regardless of the place and time where it is used. The expression in its applicability is more presumptuous than active.

Other authors such as Vare and Scott (2007), incorporate other elements in this analysis. He argues that the importance of the term is not only semantics, but its definition. They consider sustainability to be a continuous learning process whose purpose is to keep the human species in a healthy and livable environment. Everything, through the improvement of the human condition, based on a system that lasts indefinitely and without exhausting itself. The authors demonstrate that sustainability is not an end in itself, but is a continuous learning process where the purpose is the maintenance of life on the planet.

Meanwhile, another author like Solow (1993), although he does not question the terms set out, defines sustainability as more than a slogan or the expression of an emotion, he promotes the preservation of productive capacity on an indefinite horizon. In other words, it raises the idea of maintaining natural capital for the future. The author does not discuss the semantic delimitation of the word, but rather accepts its natural name with its meaning and the characteristics that accompany it; the idea of maintenance, the man-nature correlation and especially justice between generations.

In this sense, it is worth noting what Folch (2008) supposes, this author expresses that sustainability is not yet a theory, nor a paradigm, but rather, a manifestation of a rational illusion based on the own need for progress in humanity. It considers that in the matter of sustainability it should be governed by an ideal of preservation during a lifetime, perhaps based on an anthropogenic vision. In any case, the purpose of the term emphasizes values that must be sufficient reason to disperse the essence of humanity within a system of life.

HIGUERA-ZIMBRÓN, Alejandro \& RIVERAGUTIÉRREZ, Erika. Sustainable or Sustainability?. Journal of Social Researches. 2020 
By way of reflection, the argumentation between authors on the semantics of the terms is not in itself a discussion that reveals elements of a debate, but rather, the approaches deal with the purpose of the expressions. Perhaps sustainability, unlike sustainability, denotes a more complete vision when it comes to biocentric issues, which are the core of life within a system based on interrelated behavioral mechanisms. It is de facto a requirement for life to continue indefinitely and for human culture to develop over many centuries. For that reason, the impacts of human activities must remain within certain limits. In order that the diversity, complexity and functions of the system that support planetary life are not destroyed.

The idea of sustainability, beyond sustainability, requires assuming a versatile behavior based on ethical and moral principles, capable of including quantifiable and qualitatively indispensable variables for the formation of new lifestyle patterns. It is confirmed that biocentric systems must be sustained indefinitely.

\section{The praxis of sustainability or sustainability.}

In this case, the research is supported by international forums, international public policies and strategies, as a mechanism for the practical continuity or application of the sustainable or sustainable expression, whose evidence is shown in the background of the environmental crisis of the last century. and of this century. Although the environmental issue is not new, it has been confirmed, based on existing data, that in the past some physiocrats recommended carefully conserving land as the only true source of real wealth. However, in the early 1960s, scientific reports began to be produced that characterized the outbreak of the environmental crisis.

\section{International forums.}

Everything arises when one of the first reports, the silent spring by Rachel Carson (1962), denounced the repercussion of the use of pesticides such as DDT (Dichloro diphenyl trichloroethane) used in agriculture that was dispersed in the environment, and this could being the cause of multiple diseases not only in humans, but would also cause countless negative impacts on biodiversity.
For this reason, soon after, in 1971, the report by Meadows and the Club of Rome (1972), The limits of growth based on the results of a mathematical model (World 3), in which the alarm is activated, was presented. contemporary environmental for the following reasons; environmental degradation; uncontrollable urban expansion; job insecurity; alienation of youth; rejection of the value system of society; population increase; economic shocks; among others.

Consequently, the results reached by the group of scientists generated controversy in the world. In sum, if trends in world population growth, industrialization, environmental pollution, food production, and the depletion of natural resources were maintained, this planet would reach the limits of growth in the course of a hundred years after the publication of the study, is say, around the year 2072.

In response to these data, the political sector decided to strengthen decision-making to benefit the maintenance and conservation of the environment in order to reverse the relentless prognosis. In other words, work on the elaboration of laws, regulations and norms, that promulgate policies to develop plans or projects, that direct actions, among others. At the same time, design summits, forums, conferences and meetings, with the goal of disseminating and establishing measures to mitigate this scenario.

Faced with the worrying prospects posed by The Limits to Growth, the United Nations (UN) commissioned a group of experts coordinated by Ignacy Sachs to define a reference term that would be compatible with the notions of development and conservation of the environment. Consequently, for 1974 in the Declaration of Cocoyoc Mexico, the term ecodevelopment was born, as an alternative to the consumption model of the industrial and commercial system of developed countries. However, Henry Kissinger (national security adviser in the United States of America) expressed his disapproval to the United Nations Environment Program (UNEP) and demanded to "touch up" that word. In such a way that the members of the UN were forced to look for a new term that easily adapted to the economic model of the industrial countries. 
According to Naredo (1996) in Rivera Hernández (2017), the word ecodevelopment was replaced by sustainable development, an ideal term for more conventional economists to accept it, due to its meaning, probably more oriented to exalt the issues of neoliberalism.

Shortly thereafter, in 1987, the World Commission on Development and Environment (WCED) published the report under the title Our Common Future. This report reveals the term of sustainable development, which has been coined by a countless authors from various disciplines, Gil (2020), Tomasini et al (2020), Boada Ortiz., et al (2017), Martín-López, et al (2017), Comenarejo (2016), Austermühle (2015), Vilches and Gil (2015), RBG de Segura (2014), Novo (2009), Miller (2007), Aguilar (2007), Gallopín (2003), Nebel (1999), Jiménez (1997), Daly (1997), Jacobs (1995), among others. However, for the year 1992, said construct was consolidated at the so-called Earth Summit in Rio de Janeiro Brazil. It is in this event that the actors complement the term of sustainable development, incorporating the issue of improvement in the quality of human life without exceeding the carrying capacity of the ecosystems that support it. It is argued that a sustainable economy aims to maintain the natural resource base, but developing through the adaptation of knowledge, organization and technical efficiency. Therefore, sustained growth was renamed as sustainable development. However, a contradiction arose between the ecological system subject to physical limits, and the economic system promoting growth in perpetuity, the so-called holy grail of the economy according to the French Sergei Latouche.

Subsequently, in the year 2002 in the Declaration of Johannesburg South Africa, politicians defined sustainable development as the process by which socioeconomic needs, cultural diversity and a healthy environment are met, without jeopardizing their satisfaction. needs in future generations. In this forum, an ideological formula was also generalized, with which technocrats, industrialists and academics continue, at least in the discourse with their capitalist productivism.

Everything, according to the actors, after having made the ecological corrections of the industrial system, seen as essential, but that in operation has left many doubts.
The magic formula was considered to be sustained growth under sustainable development. Of course very debatable in terms of results, although there are always those who have another opinion. For example: As of 2018, according to $\mathrm{Al} \mathrm{Gore,} \mathrm{former} \mathrm{vice} \mathrm{president} \mathrm{of}$ the United States of America in the government of President Bill Clinton, he affirms that the issue of climate change has improved substantially.

Political approach to sustainability.

To determine the use of the term sustainability or sustainability, a frequency analysis was carried out in the application from the political point of view. Some of the official documents and government policy positions were simply reviewed. From an international perspective in the documents of the United Nations, the Action Plan Agenda 21 and the National Strategies by some Sectors.

Policies promoted by the United Nations Organization.

The United Nations Sustainable Development Division is part of the New Yorkbased Department of Economic and Social Affairs. The Division promotes sustainable development by providing substantive secretariat services to the United Nations Commission on Sustainable Development (CSD) and carrying out technical cooperation and capacity-building activities at the international, regional and national levels (UN, 2010).

The Commission on Sustainable Development is a high-level forum on sustainable development that reviews and monitors progress made at the national, regional and international levels in the implementation of Agenda 21, the Barbados Program of Action and the Plan of Implementation of the Johannesburg Decisions and reports thereon. The Commission meets every year in New York, and its work is organized into biennial cycles consisting of one review session and one policy-making session.

Annex 1 shows that in forums from 1992 to 2005 , there are a number of approaches without contradiction of the term. In most events, there is a clear reference to the term sustainability. 
In the features characterized by events, goals and declarations, the issue of sustainability is specifically mentioned as that which distinguishes issues of temporality and above all progress. There are no controversial arguments between the description of sustainability or sustainability, each of the periods considered, they are mostly approaches based on important acts, without mentioning the objective of each of the precepts of sustainability.

\section{Action plan agenda 21}

Agenda 21 or Agenda 21 is a Global Action Plan whose final objective has been to promote sustainable development and preservation of the environment, through the participation of various sectors. Above all, it aims to involve the inhabitants of some place through the design of a way of life that can be sustainable; in any case, it pursues the quality of future generations, it aspires to the social, environmental and economic integration of some community. Therefore, it requires local administration and the community to work on the design and operation of action plans to achieve sustainable development.

In this sense, (see annex 2) some of the networks of cities towards sustainability are exposed, as a strategy to establish a working mechanism between different places, whose purpose is to establish intra and interinstitutional agreements for the solution of common problems. This annex shows some networks that by importance have been established over the years through links on topics of similar importance. Some of them established in Latin American and Latin American cities, particularly in Spain, Brazil, Colombia and Mexico. Each of the networks provides information that enriches nations in the search for common best practices. It should be noted, in terms of sustainability and sustainability, it is only the Mexican network of cities for sustainability that makes a different name about sustainability. Otherwise, that is, the other networks do not see the term in any other way than networks for sustainability. The spirit of the object is the same, there are no elements that distinguish one from the other with respect to the other networks. They all obey very similar actions and goals, but they are applied in different contexts.

National strategies by sector.
Now, in relation to the term sustainability or sustainability, it is used permanently in the strategic plans of some sectors, particularly in Mexico. The national strategy as it refers, is focused on energy, social, environmental and tourist issues as examples in this case. In the energy part, the discourse frames the sustainability of the resource over the years, especially as it is a non-renewable natural resource. At the same time, there is a correlation between the part of the natural resource and consumption or with social aspects. In both cases, it is confirmed that use by society must always have the attitude of sustainability, since conscious consumption is an obligation as it is a strategic area in all nations.

Similarly, other strategies designed in Europe argue the importance of making the sustainable use, management and protection of natural capital compatible with the well-being of citizens, in addition to establishing cooperation priorities based on the needs of the countries, promoting of the environment within the framework of sustainable development, and on the basis of these priorities, the strategy document presents the actions to be carried out, according to the modalities of their execution. However, regarding the situation of this issue, there are no elements that contravene the question of sustainability and sustainability; The term sustainability is used naturally.

Therefore, the questions that arise are: What is the frequency of use of the term sustainable or sustainable among authors? What is the most common use in Latin America or Latin America? Is the way of writing the term implausible or is its meaning more important?

\section{Methodology}

Once the research problem has been identified through the description of its supported elements from a scientific literary review, it is up to this section to limit the selection criteria to determine the studies that support the research. These elements correspond to: Type of study, approach, design, methodology, instruments, procedures, data collection and analysis, among others (Hernández, Fernández-Collado, and Baptista, 2008). 


\section{Method, Population and Sample}

The purpose of this study was to identify the frequency of use of the word sustainable or sustainable. To achieve this objective, we worked under the systematic reviews (SR) method. SRs are defined as a scientific investigation with which the literature on a topic is reviewed starting from one or several clear and objective formulated questions, through different systematic methods to identify, select and critically evaluate the investigations that address the questions (Gisbert and Bonfill, 2004). In addition, according to the authors who consider that they are scientific investigations that use a method to synthesize the results of the original studies. It is clarified that an intentional sampling was determined. In this case, SR was characterized by: a) synthesis and analysis of information with a practical approach, b) was based on the best available scientific evidence, c) clearly defined questions were asked, and d) systematic and explicit methods were used. to identify and select studies, critically evaluate them, extract the data of interest to analyze.

\section{Instrument}

This research used the Cochrane Handbook of Systematic Reviews for Interventions to guide researchers in preparing systematic reviews under the Cochrane Intervention Methodology. The complete manual is published on the Internet (cochrane.org). In this case, the instruments of the Cochrane protocol were used (see annex 1-2). They include precise information on each of the sections that are completed on a mandatory basis and must be approved to be considered a systematic review.

\section{Procedure}

To achieve the purpose and answer the research questions, the following activities were carried out in the order specified. The steps for conducting a systematic review are listed below and are adapted from the Cochrane Collaborative Reviewers Manual. The sections are as follows:

1. Formulation of the problem based on scientific evidence.
2. Location and selection of studies. Identification of studies by searching for references. It was determined to do an intentional sampling on those studies that addressed any research question, inclusion and exclusion criteria related to language and time range. At the same time, the following characteristics were considered: (a) investigations that propose concepts, regulations, policies, forums, plans and strategies, (b) that include the participation of leading authors on the subject, (c) studies carried out in the Spanish language, (d) those that were made 10 years ago. Consequently, we searched for references as wide as possible in formal and informal sources. Among the formal ones they consulted specialized databases such as ERIC, ProQuest, Scopus, Latinindex and Redalyc, as well as specialized magazines on issues of sustainable development. Unpublished studies, conference proceedings, some international forums, plans and programs of some government institutions, electronic media magazines without indexing were considered in informal sources.

3. The quality of the information was evaluated. For this, the following criteria were considered, (a) referent, (b) conceptualization of the construct, (c) argumentation, (d) characterization of the construct, (e) temporality, (f) written in Spanish.

4. Data extraction was based on content analysis and synthesis, considering the background, state of the art, methods, results, discussion and conclusion.

5. The results are presented for discussion and graphic displays.

\section{Results}

In this section it is essential to remember the purpose of the research: (1) What is the frequency of use of the term sustainable or sustainable among authors? (2) What is the most common use in Latin America or Latin America? (3) Is the way of writing the term implausible or is its meaning more important? Therefore, the following results were obtained: 
The search for information in the previously commented databases, based on the location and selection of information, in addition to the criteria indicated above, before the following sample: (a) 40 articles, (b) International Summits from 1992 to 2013, (c) Networks of Cities towards Sustainability made up of more than 30 members, and (d) National strategies including the 28 countries of the European Union. Therefore, the results are broken down in a particular way:

\section{Answer question 1: Journal articles by keyword}

Information from 40 magazines that represent the total of a sample.

\begin{tabular}{|l|l|r|r|}
\hline \multicolumn{2}{|l}{ General Articles (40) } & No & $\%$ \\
\hline \multirow{2}{*}{ Word Frequency } & Sustainable & 35 & 90 \\
\cline { 2 - 4 } & Sustainable & 5 & 10 \\
\hline \multirow{2}{*}{ Definition } & Sustainable & 30 & 80 \\
\cline { 2 - 4 } & Sustainable & 10 & 20 \\
\hline Application & Sustainable & 38 & 95 \\
\cline { 2 - 4 } & Sustainable & 2 & 5 \\
\hline
\end{tabular}

Table 1 Frequency of the word sustainable or sustainable Source: self made

The result of Table 1, shows the number of magazines in which the word sustainable is present and the rest that refer to the word sustainable.

\section{Answer question 2: International Summits}

The results of Table 2 (see Annex 1), which refers to the Common use in Latin America and Latin America, confirms that all the documents prepared at the summits. Particularly on policies, the term sustainability is used. Adapted from: United Nations Organization. Various documents.

In general, Table 2 presents data from the year 1992 to the year 2017 where events are defined, plans, programs or strategies are established and evidence is shown from the text that confirms the frequent use of the word sustainable. In particular, said Table shows a series of characteristics with names about sustainability, it does not refer to the word sustainable.

\section{Answer question 3: City networks towards sustainability}

Table 3 (see annex 2), Denomination. Comparative of city networks towards sustainability argues that there are countless networks that combine the theme of urban, regional and metropolitan, and the term of sustainability. In most networks, the use of the term sustainability of cities or urban sustainability is stated in the main objective. The only case that is called different is the one that occurs in Mexico, a Mexican network of cities towards sustainability.

Information was obtained from more than 200 networks located on various continents. Of these, it was found that most of them have a general denomination of sustainability.

\section{Answer question 4: National Strategies}

The results of Table 4 (see annex 3), Name: Comparison of national strategies by sector, in the case of Mexico, maintain that based on the strategies used by sector that will be or are developed from the vision of sustainability, In other words, it is detected that there are political variables that allow us to understand that work will be carried out everywhere under the concept of preserving or maintaining. Not the opposite, what must be sustained, however, it is stated that it has been a habitual use in Mexico without there being.

\section{General conclusion}

In summary, it is worth remembering that the objective of this document was to understand what is the most frequent semantic use of the term sustainable or sustainable. Therefore, to achieve this, a referential framework of the term was established, contemplating various sections: The origins of the term, the literature review and the most frequent praxis.

For all the above, it could be verified that the Saxon Hans Carl von Carlowitz introduced the expression nachhaltendes wirtschaften, which means: Sustainable administration, for its translation into German. It is confirmed that the English translated it by sustainable yield which means sustainable production and is probably the origin of this divergence from sustainable or sustainable use, as evidenced by the various positions presented. 
Likewise, various authors warn that the expression "sustainable development" or "sustainable development" is a mistranslated Anglicism, but increasingly used and accepted not for its frequent use but for its semantics.

It is confirmed that the word sustainable has been erroneously translated into Spanish as "sustainable". There is evidence that this interpretation was made at the Rio de Janeiro Brazil conference in 1992 by environmentalists from Latin America with anthropocentric (sustainable) perception, who consider the human being only, and not with due perception, such as biocentric (sustainable) ) that considers everything inherent in life.

From the practical sphere, that is, politically and institutionally, sustainable development, first refers to the improvement in the quality of human life without exceeding the carrying capacity of the ecosystems that support it. Second, achieving this purpose requires a "sustainable economy" construct that is clearly defined but in practice is still ignored. Regarding the term, there is no evidence, due to the systematic review that was carried out, that the sustainable denomination is used in the documents presented, it is only confirmed that its use is more frequent in Mexico. In Latin America and Latin America the most common use is the word "sustainable".

Finally, it is emphasized that the term sustainability denotes a semantic and grammatical, theoretical and political congruence. In contrast, the word sustainability is used in Mexico more frequently, however, it is recognized for its meaning, it is understood that every day it is applied in different contexts without breaking with the spirit of the meaning of the word.

\section{References}

Aguilar, P. G. (2007). Decrecimiento: camino hacia la sostenibilidad. El ecologista, (55), 2008. Recuperado de http://titulaciongeografiasevilla.es/contenidos/profesores/materiales/arch ivos/Pepa_Decrecimiento.pdf

Álvarez, W. T. S., León, A. M., Nogueira, D. M., Cabrera, H. R., \& Medina, P. E. S. (2020). Vínculo universidad-empresa para el desarrollo local sustentables en PyMES turísticas. Universidad y Sociedad, 12(1), 350-358.

ISSN: 2414-4835

ECORFAN ${ }^{\circledR}$ Todos los derechos reservados
Austermühle, S. (2015). Sostenibilidad y ecoeficiencia en la empresa moderna [Capítulo 1]. Universidad Peruana de Ciencias Aplicadas (UPC). Recuperado de https://repositorioacademico.upc.edu.pe/bitstrea $\mathrm{m} /$ handle/10757/347185/UPC+libro+sostenib.+ $\mathrm{y}+$ ecoef.+interiores.pdf? sequence $=1$

Bifani Paolo (1993). "Desarrollo Sostenible, población y pobreza: algunas reflexiones conceptuales". En Educación Ambiental y Universidad, Universidad de Guadalajara, México. Recuperado el 14 de noviembre de 2018 de:

http://www.eurosur.org/medio_ambiente/bif19. $\mathrm{htm}$

Boada Ortiz, A., Rocchi, S., \& Kuhndt, M. (2017). Negocios y sostenibilidad: más allá de la gestión ambiental. Recuperado de http://190.131.241.186/handle/10823/781

Carlowitz y la evolución del Término Sostenible y Sustentable. Hans Carl von Carlowitz, nació el 14 de diciembre de 1645 en el Castillo de Rabenstein, en Chemnitz. Autor del libro "Sylvicultura oeconomica" publicado en 1700 . Véase

http://tufreiberg.de/ressourcenprofil/pdf/Text $\%$ 20Grober\%20spanisch.pdf

Carson., R. (1962). The silent spring. Booket: España

Cedeño, A. R., Lopez, L. V., \& Zambrano, J. L. Á. (2020). Revisión Teórica sobre la innovación en el desarrollo del turismo sostenible y su influencia socio ambiental. ECA Sinergia, 11(1), 133-143.

Celi, M. 2007. Derecho ambiental. Hacia un desarrollo sostenible. Edit. ABC S.A.C. TrujilloPerú

Colmenarejo, R. (2016). Enfoque de capacidades y sostenibilidad Aportaciones de Amartya Sen y Martha Nussbaum. Ideas $y$ valores, 65(160), 121-149. Recuperado el 20 de abril de https://s3.amazonaws.com/academia.edu.docum ents/44287950/6._Colmenarejo.pdf?AWSAcces sKeyId=AKIAIWOWYYGZ2Y53UL3A\&Expi res $=1559667486 \&$ Signature $=$ wvTmNdL3SqV Nt7MS\%2FKiejdikwQA\%3D\&responsecontentdisposition=inline $\% 3 \mathrm{~B} \% 20$ filename $\% 3 \mathrm{DColme}$ narejo_R._2016_._Enfoque_de_capacid.pdf

HIGUERA-ZIMBRÓN, Alejandro \& RIVERAGUTIÉRREZ, Erika. Sustainable or Sustainability? Journal of Social Researches. 2020 
Comisión Mundial de Medio Ambiente y Desarrollo. (1987). Our Common Future. Oxford University Press. Oxford

Creswell, J. W. (2009). Research design: Qualitative, quantitative, and mixed methods approaches. Los Angeles: Sage.

Daly, H. E., \& Von Droste, B. (1997). Medio ambiente y desarrollo sostenible: más allá del informe Brundtland (No. 333.7 MEDamb). http://www.sidalc.net/cgi-

bin/wxis.exe/?IsisScript=FCEAL.xis\&method= post $\&$ formato $=2 \&$ cantidad $=1 \&$ expresion $=\mathrm{mfn}$ $=000620$

De Segura, R. B. G. (2014). Del desarrollo sostenible según Brundtland a la sostenibilidad como biomimesis. Recuperado de http://erevistas.saber.ula.ve/index.php/ecodisen o/article/viewFile/8050/7995

Diccionario de la Real Academia de la Lengua Española. (2014). Diccionario de la Lengua Española $\left(23^{\circ}\right.$. Ed). Consultado en http://www.rae.es/rae.html

Escobar, E. C. (2015). Panorama regional del desarrollo sostenible en américa latina. Luna azul, (40), 195-212. Recuperado de http://www.scielo.org.co/scielo.php?pid=S1909

$24742015000100013 \&$ script=sci_arttext\&tlng= en

Folch, R. (1998). Ambiente, emoción y ética. Barcelona: Ed. Ariel.

Fraume, N. 2008. Diccionario Ambiental. Eco Ediciones. Bogotá-Colombia.

Gallopín, G. C. (2003). Sostenibilidad y desarrollo sostenible: un enfoque sistémico. CEPAL. Recuperado de: https://repositorio.cepal.org/handle/11362/5763

Gudynas Eduardo (1992). "Los múltiples verdes del ambientalismo latinoamericano". Nueva sociedad número 122 noviembre- diciembre 1992.

Gil, C. (2020). El desarrollo sostenible como principio guía para la responsabilidad empresarial en Venezuela: Una base ética. Tekhné, 23(1).
Gisbert, J., \& Bonfill, X. (2004). ¿Cómo realizar, evaluar y utilizar revisiones sistemáticas y metaanálisis? Gastroenterol Hepatol; 27(3):129-49. Recuperado de http://www.elsevier.es/en/node/2030405

Hernández Sampieri, R., Fernández Collado, C., \& Baptista Lucio, P. (2010). Metodología de la investigación (Vol. 3). México: McGraw-Hill. Higuera Zimbrón A., Rubio Toledo, M. et al (2016). Diseño estratégico sostenible. Fundamentos teóricos y aplicaciones Éticas para el comercio justo y las comunidades autopoiéticas. Recuperado el 01 de octubre de 2018

http://hdl.handle.net/20.500.11799/58599

Jacobs, M. (1995). Economía Verde: Medio ambiente y desarrollo sostenible (No. 333.7 J17e). Bogotá, CO: Tercer Mundo Ed. Recuperado de http://www.sidalc.net/cgibin/wxis.exe/?IsisScript=earth.xis\&method=pos $\mathrm{t} \&$ formato $=2 \&$ cantidad $=1 \&$ expresion $=\mathrm{mfn}=02$ 3320

Jiménez Herrero, L. M. (1997). Desarrollo sostenible y economía ecológica. http://repositorio.cenpat-

conicet.gob.ar:8081/xmlui/bitstream/handle/123 456789/477/desarrolloSostenibleYecoEco.pdf?s equence $=1$

Lacherre, M. R. (2018). Sostenible o sustentable. SAGASTEGUIANA, 1(2), 91-92. Recuperado el 18 de abril de 2019 de http://revistas.unitru.edu.pe/index.php/REVSA GAS/article/view/1798

Marquardt Bernd (2006). "Historia de la sostenibilidad. Un concepto medioambiental en la historia de Europa central (1000-2006)", en Dossier Historia y geografía. Julio-diciembre 2006. Páginas 172-197. En Universidad de los Andes. Revista Historia Crítica. ISSN 19006152

Márquez, R. A. (2010) Sostenible y sustentable, Analítica. com (en línea). Disponible en http://www.analitica.com/bitblio/amarquez/sost enible.asp.

Martins, A. a., Mata, T. M., and Costa, C. a. V. Martín-López, B., González, J. A., Vilardy, S. P., Montes, C., García-Llorente, M. (2006). Education for sustainability: challenges and trends. Clean Technologies and Environmental Policy, 8(1), pp. 31-37.

HIGUERA-ZIMBRÓN, Alejandro \& RIVERAGUTIÉRREZ, Erika. Sustainable or Sustainability?. Journal of Social Researches. 2020 
Meadows, Donella H. \& Club of Rome. (1972). The Limits to growth; a report for the Club of Rome's project on the predicament of mankind. New York: Universe Books.

Méndez, M. (2012). La Sostenibilidad y la Sustentabilidad en los museos, dos enfoques principales: la museología tradicional y la nueva museología; estudio de caso en dos museos de la provincia de Pichincha. Tesis previa a la obtención de títulos de licenciada en restauración y museología. Universidad Tecnológica Equinoccial.

Miller, G. T. (2007). Ciencia ambiental, desarrollo sostenible: un enfoque integral (No. 333.7 M653ci). México, MX: Thomson. Recuperado de http://www.redalyc.org/pdf/1794/17942081801 $0 . p d f$

Naredo, J.M. (1996). Sobre el origen, el uso y el contenido del término sostenible. Textossobre sostenibilidad. Cuadernos de investigación urbanística, 41, 7-18. Recuperado dehttps://dialnet.unirioja.es/servlet/articulo?codigo $=1333758$.

Nebel, B. J., \& Wright, R. T. (1999). Ciencias ambientales: ecología y desarrollo sostenible.

Novo, M. (2009). La educación ambiental, una genuina educación para el desarrollo sostenible Environmental Education, a genuine education for sustainable development. Revista de educación, 195-217.

Otero, C. S. D. P. Y. (2010). Hacia una cultura de la sostenibilidad a través de los textos de Goethe. Revista de Filología Alemana, 18. Recuperado el 05 de septiembre de 2018 de, http://www.redalyc.org/html/3218/3218276350 $03 /$

Rivera-Hernández, J. E., Blanco-Orozco, N. V., Alcántara-Salinas, G., Houbron, E. P., \& PérezSato, J. A. (2017). ¿Desarrollo sostenible o sustentable? La controversia de un concepto. Posgrado y Sociedad. Revista Electrónica del Sistema de Estudios de Posgrado, 15(1), 57-67. https://investiga.uned.ac.cr/revistas/index.php/p osgrado/article/view/1825
Roldan-Guzmán, Y. M. (2020). Economía y desarrollo humano sostenible. Revista Científica FIPCAEC (Fomento de la investigación y publicación en Ciencias Administrativas, Económicas y Contables). ISSN: 2588-090X. Polo de Capacitación, Investigación y Publicación (POCAIP), 5(16), 278-289.

Schmithüsen, F. J. (2013). La sostenibilidad aplicada en el sector de las actividades forestales cumple 300 años. Working papers/Forest Policy and Forest Economics Department of Forest Sciences. International series, 2013(3). Recuperado el 05 de septiembre de 2018 de https://www.research-

collection.ethz.ch/bitstream/handle/20.500.1185 0/154088/eth-7349-01.pdf?sequence $=1$

Sieferle, Rolf, (2003). Der Europäische Sonderweg: Ursachen und Faktoren, 2a. ed., Stuttgart, Breuninger.

Solow, Robert, (1993). "An almost practical step toward sustainability," In: Resources Policy, Elsevier, vol. 19(3), pages 162-172, September.

Tomasini, D., Longo, L., Puhl, L., Maggi, A., \& Cirigliano, S. (2020). Sostenibilidad productiva y económica de la conservación de suelos en la Región Oriental de la provincia de Entre Ríos. Agronomía \&Ambiente, 39(2).

Tudela, F. (1992). La sustentabilidad del desarrollo. Problemas del desarrollo, 23(91), 27-30. Recuperado el 14 de noviembre de 2018 de

https://www.jstor.org/stable/pdf/43838091.pdf? seq=1\#page_scan_tab_contents

Ulrich Grober, "Von Freiberg nach RioCarlowitz und die Bildung des Begriff $\mathrm{s}$ Nachhaltigkeitin," in Die Erfi ndung der Nachhaltigkeit. Leben, Werk und Wirkung des Hans Carl von Carlowitz, ed. Sächsische Carlowitz-Gesellschaft (Munich 2013), 13-30; and Franz Josef Radermacher, "Die Ressourcen der Erde setzen uns Grenzen-vom säch- Ruth Oldenziel and Helmuth Trischler 11 sischen Bergmann Hans Carl von Carlowitz 1713 bis zum neuen Report an den Club of Rome 2052," in ibid., 141-156

Vare, P. \& Scott, W. (2007). Learning for a Change: Exploring the Relationship Between Education and Sustainable Development. Journal of Education for Sustainable Development, 1(2), pp. 191-198.

HIGUERA-ZIMBRÓN, Alejandro \& RIVERAGUTIÉRREZ, Erika. Sustainable or Sustainability? Journal of Social Researches. 2020 


\section{Annex 1}

International Summits. (Answer question 2)

\begin{tabular}{|c|c|c|c|}
\hline Year & Event & $\begin{array}{ll}\text { Plan } & / \\
\text { program } & / \\
\text { strategy }\end{array}$ & $\begin{array}{l}\text { Textual statement } \\
\text { (evidence) }\end{array}$ \\
\hline 1992 & $\begin{array}{l}\text { Earth Summit } \\
\text { held in Rio de } \\
\text { Janeiro (Brazil) }\end{array}$ & $\begin{array}{l}\text { Commission on } \\
\text { Sustainable } \\
\text { Development } \\
\text { (DS) }\end{array}$ & $\begin{array}{l}\text { PRINCIPLE 4. To } \\
\text { achieve sustainable } \\
\text { development, the } \\
\text { protection of the } \\
\text { environment shall } \\
\text { constitute an } \\
\text { integral part of the } \\
\text { development } \\
\text { process. }\end{array}$ \\
\hline 1994 & $\begin{array}{l}\text { Sustainable } \\
\text { Development of } \\
\text { Small Island } \\
\text { Developing } \\
\text { States. } \\
\text { Bridgetown B. }\end{array}$ & $\begin{array}{l}\text { Barbados } \\
\text { Action } \\
\text { Program, in } \\
\text { which specific } \\
\text { actions and } \\
\text { measures are } \\
\text { proposed to } \\
\text { promote } \\
\text { sustainable } \\
\text { development. }\end{array}$ & $\begin{array}{l}\text { PART 2-1. Small } \\
\text { island developing } \\
\text { States, in } \\
\text { accordance with } \\
\text { their own priorities, } \\
\text { should seek to } \\
\text { achieve } \\
\text { objectives of the } \\
\text { SD. }\end{array}$ \\
\hline 1997 & $\begin{array}{l}\text { Earth Summit + } \\
\text { 5) held in New } \\
\text { York (United } \\
\text { States } \\
\text { America) }\end{array}$ & $\begin{array}{l}\text { Plan for further } \\
\text { implementation } \\
\text { of Agenda 21, } \\
\text { work program } \\
\text { of the } \\
\text { Commission on } \\
\text { Sustainable } \\
\text { Development. }\end{array}$ & $\begin{array}{l}\text { REITERATING } \\
\text { sustainable } \\
\text { development in its } \\
\text { economic, social } \\
\text { and environmental } \\
\text { aspects is a } \\
\text { fundamental } \\
\text { element of the } \\
\text { United Nations ... }\end{array}$ \\
\hline 2002 & $\begin{array}{l}\text { The World } \\
\text { Summit on } \\
\text { Sustainable } \\
\text { Development, } \\
\text { held in } \\
\text { Johannesburg, } \\
\text { South Africa. }\end{array}$ & $\begin{array}{l}\text { Johannesburg } \\
\text { Decisions } \\
\text { Implementation } \\
\text { Plan, } \\
\text { containing an } \\
\text { approach with } \\
\text { concrete } \\
\text { measures. }\end{array}$ & $\begin{array}{l}\text { STATEMENT NO } \\
26 \text { Sustainable } \\
\text { development } \\
\text { requires a long- } \\
\text { term perspective } \\
\text { and broad } \\
\text { participation in } \\
\text { policy formulation }\end{array}$ \\
\hline 2005 & $\begin{array}{l}\text { Barbados } \\
\text { Program of } \\
\text { Action for the } \\
\text { Sustainable } \\
\text { Development of } \\
\text { Small Island } \\
\text { States ... }\end{array}$ & $\begin{array}{l}\text { Mauritius } \\
\text { strategy for the } \\
\text { further } \\
\text { implementation } \\
\text { of the Barbados } \\
\text { Program of } \\
\text { Action. Port } \\
\text { Louis } \\
\text { (Mauritius). }\end{array}$ & $\begin{array}{l}\text { DECLARATION } \\
3 . \quad \text { Incorporate } \\
\text { national principles, } \\
\text { strategies, } \\
\text { strengthen political } \\
\text { commitments and } \\
\text { awareness of } \\
\text { sustainable } \\
\text { development ... }\end{array}$ \\
\hline 2006 & $\begin{array}{l}\text { - High Level } \\
\text { Dialogue on } \\
\text { International } \\
\text { Migration and } \\
\text { Development. }\end{array}$ & $\begin{array}{l}\text { Millennium } \\
\text { Development } \\
\text { Goals Mexico. }\end{array}$ & $\begin{array}{l}\text { STATEMENT. } \\
\text { The government's } \\
\text { main objective is to } \\
\text { implement social } \\
\text { public policies with } \\
\text { sustainability } \\
\text { criteria ... }\end{array}$ \\
\hline 2008 & $\begin{array}{l}\text { - Monterrey } \\
\text { Consensus. } \\
\text { Meeting on the } \\
\text { Millennium } \\
\text { Development } \\
\text { Goals. }\end{array}$ & $\begin{array}{l}\text { Doha } \\
\text { Declaration of } \\
\text { the Follow-up } \\
\text { International } \\
\text { Conference on } \\
\text { Financing for } \\
\text { Development. }\end{array}$ & $\begin{array}{l}\text { DECLARATION } \\
\text { 1. Commitment is } \\
\text { made to eradicate } \\
\text { poverty, achieve } \\
\text { sustained economic } \\
\text { growth and } \\
\text { promote } \\
\text { sustainable } \\
\text { development ... }\end{array}$ \\
\hline 2009 & $\begin{array}{l}\text { - United } \\
\text { Nations } \\
\text { Conference. } \\
\text { World Financial } \\
\text { and Economic } \\
\text { Crisis and its } \\
\text { Effects on } \\
\text { Development. }\end{array}$ & $\begin{array}{l}\text { Plan to analyze } \\
\text { the worst } \\
\text { economic crisis } \\
\text { in the world } \\
\text { since the Great } \\
\text { Depression. }\end{array}$ & $\begin{array}{l}\text { STATEMENT: } \\
\text { Miguel d'Escoto } \\
\text { Brockmann. 63rd } \\
\text { session of the } \\
\text { General Assembly. } \\
\text { Maintains: The } \\
\text { historical } \\
\text { opportunity and the } \\
\text { collective } \\
\text { responsibility to } \\
\text { give a new stability } \\
\text { and sustainability } \\
\ldots\end{array}$ \\
\hline
\end{tabular}

ISSN: 2414-4835

ECORFAN $^{\circledR}$ Todos los derechos reservados

\begin{tabular}{|c|c|c|c|}
\hline 2010 & $\begin{array}{l}\text { United Nations } \\
\text { Summit on the } \\
\text { Millennium } \\
\text { Development } \\
\text { Goals }\end{array}$ & $\begin{array}{l}\text { Action plan to } \\
\text { achieve eight } \\
\text { poverty targets } \\
\text { by } 2015 \text { as well } \\
\text { as new targets } \\
\text { for women's } \\
\text { and children's } \\
\text { health, hunger } \\
\text { and disease. }\end{array}$ & $\begin{array}{l}\text { DECLARATION } \\
65 / 1 \text { Point } 11 . \\
\text { Governance and the } \\
\text { rule of law are } \\
\text { recognized at the } \\
\text { national and } \\
\text { international levels, } \\
\text { essential for } \\
\text { sustained, inclusive } \\
\text { and equitable } \\
\text { economic growth, } \\
\text { sustainable } \\
\text { development ... }\end{array}$ \\
\hline 2011 & $\begin{array}{l}\text { United Nations } \\
\text { Conference on } \\
\text { the Least } \\
\text { Developed } \\
\text { Countries }\end{array}$ & $\begin{array}{l}\text { Program of } \\
\text { Action for the } \\
\text { Least } \\
\text { Developed } \\
\text { Countries for } \\
\text { the Decade } \\
2011-2020\end{array}$ & $\begin{array}{l}\text { DECLARATION } \\
\text { POINT 5. Strategic, } \\
\text { broad and sustained } \\
\text { approach to achieve } \\
\text { in them a structural } \\
\text { transformation that } \\
\text { promotes } \\
\text { accelerated, } \\
\text { sustained, inclusive } \\
\text { and equitable } \\
\text { economic growth } \\
\text { and sustainable } \\
\text { development ... }\end{array}$ \\
\hline 2012 & $\begin{array}{l}\text { United Nations } \\
\text { Conference on } \\
\text { Sustainable } \\
\text { Development } \\
\text { (Rio +20) }\end{array}$ & $\begin{array}{l}\text { Plan. Green } \\
\text { economy and } \\
\text { lifting people } \\
\text { out of poverty, } \\
\text { and } \\
\text { international } \\
\text { coordination } \\
\text { for sustainable } \\
\text { development. }\end{array}$ & $\begin{array}{l}\text { DECLARATION } \\
66 / 288 \text {. Point } 1 . \text { We } \\
\text { renew our } \\
\text { commitment to } \\
\text { sustainable } \\
\text { development and a } \\
\text { sustainable future } \\
\ldots\end{array}$ \\
\hline 2013 & $\begin{array}{lr}\text { United } & \text { Nations } \\
\text { Forest } & \text { Forum } \\
10 . & \end{array}$ & $\begin{array}{l}\text { Strategy: } \\
\text { Central nucleus } \\
\text { of the DAES in } \\
\text { forestry policy } \\
\text { and in relation } \\
\text { to sustainable } \\
\text { development } \\
\text { issues ... }\end{array}$ & $\begin{array}{l}\text { ACTIVITIES. } \\
\text { Sustainable forest } \\
\text { management. } \\
\text { United Nations } \\
\text { Instrument on } \\
\text { Forests, the Global } \\
\text { Forest Goals }\end{array}$ \\
\hline 2014 & $\begin{array}{l}\text { Third } \\
\text { International } \\
\text { Conference on } \\
\text { Small Island } \\
\text { Developing } \\
\text { States. }\end{array}$ & $\begin{array}{l}\text { It was held in } \\
\text { Apia, Samoa, } \\
\text { encouraging } \\
\text { these countries } \\
\text { to share their } \\
\text { successful } \\
\text { experiences in } \\
\text { mitigating the } \\
\text { effects of } \\
\text { climate change. }\end{array}$ & $\begin{array}{l}\text { STATEMENT } \\
\text { POINT 5. States are } \\
\text { a special case, due } \\
\text { to their particular } \\
\text { vulnerabilities, they } \\
\text { continue to have } \\
\text { problems achieving } \\
\text { their objectives in } \\
\text { the three } \\
\text { dimensions of } \\
\text { sustainable } \\
\text { development. }\end{array}$ \\
\hline 2015 & 2030 Agenda & $\begin{array}{l}17 \text { Sustainable } \\
\text { Development } \\
\text { Goals (SDGs) }\end{array}$ & $\begin{array}{l}\text { Achim Steiner. } \\
\text { "The Agenda offers } \\
\text { a unique } \\
\text { opportunity to put } \\
\text { the world on a path } \\
\text { to more prosperous } \\
\text { and sustainable } \\
\text { development. }\end{array}$ \\
\hline 2016 & $\begin{array}{l}\text { World } \\
\text { conference on } \\
\text { sustainable } \\
\text { transport. }\end{array}$ & $\begin{array}{ll}70 / 197 . & \\
\text { Towards broad } \\
\text { cooperation } \\
\text { among all } \\
\text { modes } & \text { of } \\
\text { transport } & \text { to } \\
\text { promote } & \\
\text { sustainable } & \\
\text { multimodal } & \\
\text { transit } & \\
\text { corridors. } & \\
\end{array}$ & $\begin{array}{l}\text { DECLARATION } \\
70 / 1 . \text { Extreme } \\
\text { poverty is the } \\
\text { greatest challenge } \\
\text { facing the world } \\
\text { and constitutes an } \\
\text { indispensable } \\
\text { requirement for } \\
\text { sustainable } \\
\text { development ... }\end{array}$ \\
\hline 2017 & $\begin{array}{l}\text { Oceans } \\
\text { Conference }\end{array}$ & $\begin{array}{l}71 / 312 . \\
\text { oceans, our } \\
\text { future: call to } \\
\text { action. }\end{array}$ & $\begin{array}{l}\text { DECLARATION: } \\
\text { Goal DS 14: } \\
\text { Conserve and } \\
\text { sustainably use the } \\
\text { oceans, seas and } \\
\text { marine resources. }\end{array}$ \\
\hline
\end{tabular}

Table 2 Common use in Latin America and Latin America Source: Own elaboration with information from https://www.un.org/development/desa/es/about/conferenc es.html

HIGUERA-ZIMBRÓN, Alejandro \& RIVERAGUTIÉRREZ, Erika. Sustainable or Sustainability?. Journal of Social Researches. 2020 


\section{Annex 2}

Cities Networks to Sustainability. (Answer question 3)

\begin{tabular}{|c|c|c|c|}
\hline No & Region & Country & Objective description \\
\hline 1 & $\begin{array}{l}\text { Mur } 21 \\
\text { Network: The } \\
\text { Network of } \\
\text { Sustainable } \\
\text { Municipalities } \\
\text { of the Region of } \\
\text { Murcia, from its } \\
\text { purpose, was } \\
\text { created to } \\
\text { promote the } \\
\text { following } \\
\text { general } \\
\text { objectives. }\end{array}$ & Spain & $\begin{array}{l}\text { Develop the application } \\
\text { of the European } \\
\text { principles of the } \\
\text { Aalborg Plus } 10 \\
\text { Commitment of } 2004 \\
\text { and the objectives of the } \\
\text { Murcia Charter for } \\
\text { Sustainability of } 2007 .\end{array}$ \\
\hline 2 & $\begin{array}{l}\text { Emerging and } \\
\text { sustainable } \\
\text { cities }\end{array}$ & Colombia & $\begin{array}{l}\text { Promote the building of } \\
\text { ties, alliances, exchange } \\
\text { of experiences and good } \\
\text { practices between local } \\
\text { leaders and other } \\
\text { organizations linked to } \\
\text { the issue of } \\
\text { sustainability in the } \\
\text { region. }\end{array}$ \\
\hline 3 & $\begin{array}{l}\text { The Mexican } \\
\text { Network of } \\
\text { Cities towards } \\
\text { Sustainability - } \\
\text { RMCS }\end{array}$ & Mexico & $\begin{array}{l}\text { It is a space to improve } \\
\text { public policy and } \\
\text { develop social action, } \\
\text { which seeks to facilitate } \\
\text { the exchange of } \\
\text { successful experiences } \\
\text { and knowledge among } \\
\text { people and } \\
\text { organizations at the } \\
\text { local, state and national } \\
\text { level, involved in } \\
\text { promoting sustainable } \\
\text { urban development for } \\
\text { Mexico. }\end{array}$ \\
\hline 4 & $\begin{array}{l}\text { Sustainable } \\
\text { Cities Program } \\
\text { (PCS) }\end{array}$ & Brazil & $\begin{array}{l}\text { The networks of } \\
\text { "Sustainable Cities in } \\
\text { Latin America" seek to } \\
\text { encourage citizen } \\
\text { participation around the } \\
\text { city's public policies. } \\
\text { The PCS, an initiative } \\
\text { promoted by the Nossa } \\
\text { Sao Paulo Network, the } \\
\text { Brazilian Social } \\
\text { Network of Fair and } \\
\text { Sustainable Cities, and } \\
\text { the Ethos Institute, aims } \\
\text { to raise awareness, } \\
\text { mobilize and offer tools } \\
\text { for cities to develop } \\
\text { economically, socially } \\
\text { and environmentally } \\
\text { sustainable. } \\
\text { challenges are great } \\
\text { and, to be successful in } \\
\text { actions that contribute } \\
\text { to sustainability, the } \\
\text { involvement of citizens, } \\
\text { social organizations, } \\
\text { companies and } \\
\text { governments will be } \\
\text { necessary. }\end{array}$ \\
\hline 5 & $\begin{array}{l}\text { World } \\
\text { Association of } \\
\text { Major } \\
\text { Metropolises }\end{array}$ & $\begin{array}{l}22 \\
\text { members }\end{array}$ & $\begin{array}{l}\text { Metropolis is the global } \\
\text { association of local and } \\
\text { regional governments } \\
\text { of large cities and } \\
\text { metropolitan regions to } \\
\text { promote urban } \\
\text { sustainability. }\end{array}$ \\
\hline
\end{tabular}

\begin{tabular}{|c|c|c|c|}
\hline 6 & $\begin{array}{l}\text { From emerging } \\
\text { cities to } \\
\text { sustainable } \\
\text { cities }\end{array}$ & $\begin{array}{l}\text { Europe, } \\
\text { North and } \\
\text { South } \\
\text { America, } \\
\text { Asia and } \\
\text { Africa }\end{array}$ & $\begin{array}{l}\text { Sustainable Cities } \\
\text { Network. Aim to have a } \\
\text { platform to share } \\
\text { knowledge between } \\
\text { cities and also best } \\
\text { practices on issues } \\
\text { related to improving the } \\
\text { quality of life, always } \\
\text { with an emphasis on } \\
\text { achieving sustainable } \\
\text { cities. Among the topics } \\
\text { that have been } \\
\text { discussed in previous } \\
\text { seminars, courses and } \\
\text { exchanges are the } \\
\text { renovation of sea and } \\
\text { river port areas, } \\
\text { recovery of bays, solid } \\
\text { waste management and } \\
\text { project management. }\end{array}$ \\
\hline 7 & $\begin{array}{l}\text { The Sustainable } \\
\text { Development } \\
\text { Goals in } 100 \\
\text { Spanish cities ", }\end{array}$ & 77 cities & $\begin{array}{l}\text { The document provides } \\
\text { a state of the question } \\
\text { on sustainable } \\
\text { development at the } \\
\text { local level for all the } \\
\text { provincial capitals of } \\
\text { Spain, cities with more } \\
\text { than } 80,000 \text { inhabitants } \\
\text { and the twelve main } \\
\text { metropolitan areas in } \\
\text { our country. As a } \\
\text { whole, the } 100 \text { cities } \\
\text { analyzed make up } \\
\text { almost 50\% of the } \\
\text { Spanish population. }\end{array}$ \\
\hline
\end{tabular}

Table 3 Denomination. Comparative city networks towards sustainability

Source: own elaboration with information from https://www.un.org/development/desa/es/about/conferenc es.html

\section{Annex 3}

National Strategies. (Answer question 4)

\begin{tabular}{|c|c|c|c|c|}
\hline No & Country & Draft & Sector & Strategy \\
\hline 1 & Mexico & $\begin{array}{l}\text { Energy 2013- } \\
2027\end{array}$ & Energetic & $\begin{array}{l}\text { Strategic theme } 4 . \\
\text { The population's } \\
\text { access to energy } \\
\text { services brings great } \\
\text { benefits in terms of } \\
\text { quality of life and } \\
\text { social inclusion. } \\
\text { Through the supply } \\
\text { of drinking water, } \\
\text { efficient lighting, } \\
\text { heating, food } \\
\text { cooking, and } \\
\text { refrigeration, } \\
\text { transport } \\
\text { telecommunications, } \\
\text { energy has effects } \\
\text { that lead to better } \\
\text { education, health, } \\
\text { safety, gender } \\
\text { equality and } \\
\text { sustainability of the } \\
\text { environment and the } \\
\text { environment. }\end{array}$ \\
\hline 2 & Mexico & $\begin{array}{l}\text { Energy 2013- } \\
2027\end{array}$ & & $\begin{array}{l}\text { Strategic theme } 13 \text {. } \\
\text { To achieve the } \\
\text { sustainability of oil } \\
\text { resources, one of the } \\
\text { critical elements in } \\
\text { the definition of the } \\
\text { portfolio must be the } \\
\text { potential of the } \\
\text { projects to increase } \\
\text { the rate of restitution } \\
\text { of reserves. }\end{array}$ \\
\hline
\end{tabular}

HIGUERA-ZIMBRÓN, Alejandro \& RIVERAGUTIÉRREZ, Erika. Sustainable or Sustainability?. Journal of Social Researches. 2020 


\begin{tabular}{|c|c|c|c|c|}
\hline 3 & Finland & $\begin{array}{l}\text { National } \\
\text { Strategy for } \\
\text { Sustainable } \\
\text { Development }\end{array}$ & Energetic & $\begin{array}{l}\text { Strategic theme. } \\
\text { Make the sustainable } \\
\text { use and management } \\
\text { and protection of } \\
\text { natural capital } \\
\text { compatible with the } \\
\text { well-being of } \\
\text { citizens, as well as } \\
\text { ensure the integrity of } \\
\text { society in such a way } \\
\text { that the result allows } \\
\text { Finland to use its } \\
\text { strengths in a } \\
\text { sustainable way. }\end{array}$ \\
\hline 4 & $\begin{array}{l}\text { European } \\
\text { Union- } \\
\text { Brazil }\end{array}$ & $\begin{array}{l}\text { Strategy for } \\
\text { Brazil 2007- } \\
2013\end{array}$ & & $\begin{array}{l}\text { Strategic theme. Two } \\
\text { cooperation priorities } \\
\text { are defined according } \\
\text { to the country's } \\
\text { needs, namely, the } \\
\text { intensification of EU- } \\
\text { Brazil relations and } \\
\text { the promotion of the } \\
\text { environment within } \\
\text { the framework of } \\
\text { sustainable } \\
\text { development. Based } \\
\text { on these two } \\
\text { priorities, the strategy } \\
\text { document presents } \\
\text { the actions to be } \\
\text { carried out and their } \\
\text { modalities of } \\
\text { execution. }\end{array}$ \\
\hline 5 & Spain & $\begin{array}{l}\text { Sustainable } \\
\text { tourism } \\
\text { development }\end{array}$ & Social & $\begin{array}{l}\text { Strategic theme. } \\
\text { Contribute to the } \\
\text { development of } \\
\text { sustainable tourism } \\
\text { through supply } \\
\text { development policies } \\
\text { and strategies. } \\
\text { Development of the } \\
\text { regional tourism } \\
\text { sustainability policy. }\end{array}$ \\
\hline
\end{tabular}

Table 4 Denomination: Comparative of national strategies by sector

Source: Adapted from: United Nations Organization, 2018

\section{Annex 4}

A Systematic Review Protocol

\begin{tabular}{|c|c|}
\hline Tillc & 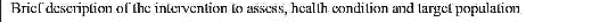 \\
\hline Protocol information & Basic information on authors, contact person, date of performing the protocol, upcates \\
\hline $\begin{array}{l}\text { Backeround and justification } \\
\text { of the study topic }\end{array}$ & $\begin{array}{l}\text { Deserintion of the scope of the investigation, health condition to assess, } \\
\text { the interention asscssed, manin effects, areas of controversy, recasons that justify performing } \\
\text { the review }\end{array}$ \\
\hline Aims & Descriplion of the primary and specilic aims, based on the research question \\
\hline $\begin{array}{l}\text { Selection criteria of the } \\
\text { studies } \\
\text { (inclusion and exclusion) }\end{array}$ & $\begin{array}{l}\text { Definition of the elieibility criteria of strdies according to type of participants, } \\
\text { the intervention, the comparator (if there is one), the outcomes, the study desigen, setting.... }\end{array}$ \\
\hline $\begin{array}{l}\text { Serarch sratalagy and sourcess } \\
\text { of information to identify the } \\
\text { studies }\end{array}$ & 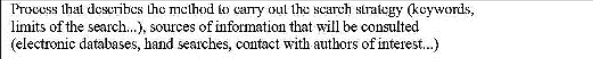 \\
\hline $\begin{array}{l}\text { Evaluation of the risk of bias } \\
\text { (or meichodologivival quality) }\end{array}$ & 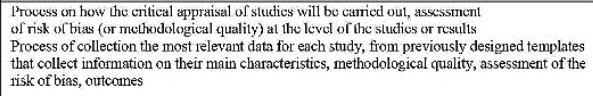 \\
\hline $\begin{array}{l}\text { Analysis and synithesis of } \\
\text { scionnlific cvidence }\end{array}$ & 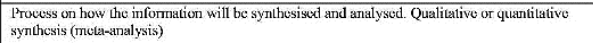 \\
\hline References & $\begin{array}{l}\text { Relevant references related to the review and other published versions of the review } \\
\text { (if there are any) }\end{array}$ \\
\hline Contlict of interest statement & $\begin{array}{l}\text { Notification of any source of conflict of interesest (financial benefit, } \\
\text { personal or profosssional prestige or promotion) }\end{array}$ \\
\hline Sourecs of linancing & Icmal : \\
\hline
\end{tabular}

\section{Figure 1}

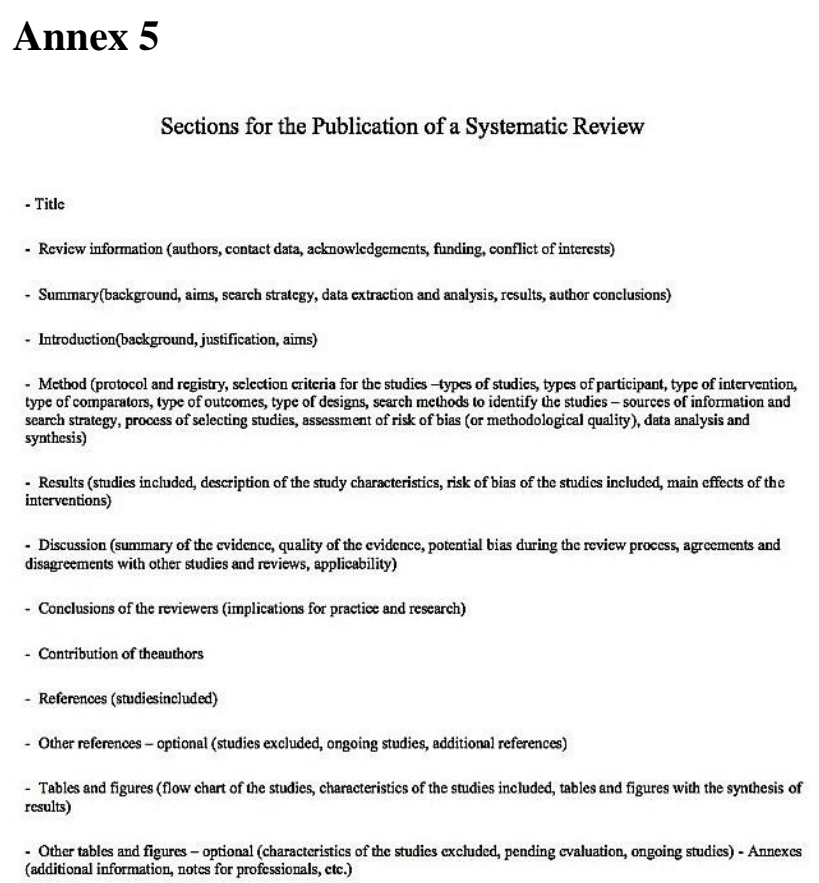

Figure 2 